\title{
Exploration and Practice of Local Economic Transformation of Automobile Marketing Professional Service from the Perspective of New Energy Automobile Industry Development
}

\author{
Xiaolian Zhang \\ Jiangxi Environmental Engineering Vocational College, Ganzhou, Jiangxi, 341000
}

Keywords: New Energy Vehicles; Automobile Marketing; Talent Training; Local Economy; Development and Transformation

\begin{abstract}
With the rapid development of China's economy, China's automobile sales and possession have increased year by year. Although the rapid development of the automobile industry has greatly promoted the progress of China's economy, it has also brought serious environmental pollution and energy consumption to China. Under this background, the new energy automobile industry has become an important way to realize the transformation of China's automobile industry and promote the sustainable development of local economy. With the rapid development of new energy vehicles, China's high-level automotive marketing professional teaching is also facing the problem of upgrading this talent training model. In the context of the new market environment, high-level jobs can only provide more and better high-quality talents for local development of the new energy automobile industry if they actively change the concept of talent cultivation, improve the corresponding curriculum, and improve students' practical ability.
\end{abstract}

\section{Introduction}

As an important pillar driving China's economic development, the automobile industry conducts research on the new energy automobile industry in the context of low-carbon economy, which is in line with the economic development strategy of sustainable development, green energy-saving development and low-carbon emission reduction implemented by the Chinese government. With the rapid development of the new energy automobile industry, local talent demand for new energy vehicle marketing is also growing. Therefore, China's higher vocational education should strive to cultivate professional automotive marketing professionals, strengthen the theoretical and practical ability of automotive marketing talents, make it better serve the new energy automobile industry, and truly contribute to the sustainable development and transformation of the local economy.

\section{Development Status of China's New Energy Automobile Industry}

According to the definition of new energy vehicles by the Ministry of Industry and Information Technology, new energy vehicles refer to vehicles driven by unconventional vehicle fuels or driven by conventional energy sources but using new vehicle-mounted power units, which have technological innovation, structural innovation, and technology. The categories of new energy vehicles are mainly divided into hybrid vehicles (HEV), pure electric vehicles (including solar vehicles, BEV for short), fuel cell electric vehicles (FCEV), hydrogen-powered vehicles and other types. Currently, according to the latest definition of new energy vehicles by the Ministry of Industry and Information Technology in 2017, the new energy vehicle category is divided into plug-in hybrid vehicles, pure electric vehicles and fuel cell vehicles.

With the increasing environmental pollution problems around the world, new energy vehicles have emerged. In China's 13th Five-Year Plan, by 2020, the annual sales volume of new energy vehicles in China will reach 2 million, and the cumulative production and sales will exceed 5 million. According to the relevant data, in 2018, the monthly sales volume of new energy vehicles in China has reached 92,000 units, an increase of 140\% compared with 2017. This can be said to be a qualitative leap. It can be seen that China's new energy automobile industry has entered a stage of 
rapid development. In recent years, China has continued to surpass the United States and become the largest country in the production and consumption of new energy vehicles. In addition, in terms of technical support for new energy vehicles, the current three vertical and three horizontal technical systems have been basically improved. China has been far ahead in the international market in terms of core technologies such as drive motors and power batteries. The new energy automobile industry represented by BYD Tang series, Beiqi EV series and Geely EV series has achieved considerable sales results. In terms of supporting facilities, the government has paid more and more attention to the construction of charging piles and charging stations, and the charging application environment is also constantly improving. In 2016, the number of charging piles in China has reached 200,000, and the proportion of charging piles for private passenger vehicles has exceeded. $80 \%$. In terms of policy support, the report of the 19th National Congress of the Communist Party of China pointed out that China's economy is in a critical period of transformational growth momentum, economic structure optimization, and economic development. General Secretary Xi Jinping also clearly pointed out that China should put green and low-carbon emerging industries at the top of the list. Under the guidance of the Chinese party and government, in 2016 and 2017, the government has successively issued a series of policies to promote the development of the new energy automobile industry, for example, to raise the threshold for entry and to impose fiscal and tax subsidies on the industry. Therefore, with the support of market environment, supporting facilities, technological innovation, policy support, etc., we can say that the new energy automobile industry can be stable and far-reaching [1].

\section{The Importance and Necessity of the Transformation of the Local Economy into the Development of New Energy Automobile Industry}

In the "13th Five-Year" National Strategic Emerging Industry Development Plan issued by the State Council of China, the important strategic position of new energy vehicles in China's sustainable economic development has also been clearly pointed out. During the 13th Five-Year Plan period, the Chinese government has successively issued a series of policies to promote the development of new energy automobile industry, including: improving the entry barriers for new energy automobile enterprises and products, and providing reasonable stage financial and tax subsidies for new energy automobile enterprises. Support the development and growth of high-quality new energy automobile enterprises. In addition, General Secretary Xi Jinping also pointed out in the recent 19th National Congress that China's economic development should move toward emerging industries such as green low-carbon, new materials and high-end equipment manufacturing, and bring emerging industries such as green low-carbon, new materials and high-end equipment manufacturing. Development has become a top priority, accelerating the development of emerging industries, building a new pillar of modern economic development, and promoting China's sustainable economic development [2].

Local development of new energy automobile industry can be said to be the current social environment development. In the context of the current environmental pollution and energy shortage problems, the adjustment of energy structure and economic structure is not only related to local energy security, environmental safety and economy. The sustainable development is related to the energy security, environmental security and sustainable economic development of the whole country [3]. According to relevant data, China's carbon dioxide emissions will exceed 42.3 billion tons by 2030, and the important factor is automobile exhaust emissions. As China's total carbon dioxide emissions rank second in the world, it is not difficult to see the grim situation of China's social environment development. New energy vehicles use unconventional vehicle fuels, which can effectively reduce carbon dioxide emissions and reduce the degree of pollution caused by the environment, which is not only conducive to regional environmental protection, but also conducive to the relief of serious environmental pollution in China [4]. In addition, with the rapid maturity of the new energy automobile industry, the improvement of people's economic conditions and the increasing concern about environmental pollution and energy shortages, more and more users of new energy vehicles are recognized throughout the country. The demand for energy vehicles is also 
rising. Therefore, the local development of the new energy automobile industry can be said to be the general trend, but also the needs of social environmental development.

Since 2010, China's economic growth rate has continued to decline. In 2016, the data dropped by $0.2 \%$ compared with last year, and the energy consumption per unit of GDP decreased by 5 percentage points. However, corporate profits and production prices showed an upward trend, and the unemployment rate declined. This is because of the increase in aggregate demand and the structural reforms on the supply side. Although China's corporate profits and economic improvement quality have improved, China's economy is still facing risks [5]. Looking at the whole year of 2016, China's new energy automobile industry has developed rapidly and has maintained an upward trend. In 2016, the sales volume and output of new energy vehicles exceeded 28 million, which made a great and outstanding improvement for China's national economy [6]. Looking ahead to the 2018, the development momentum of the new energy automobile industry is still very fast. According to the development law of the developed automobile market in China, the automobile market in China still has a lot of room for development. This is not the area where the users need car renewal and the economy. For developed regions, it is undoubtedly a rare opportunity for economic transformation and economic structural optimization. Moreover, the new energy automobile industry has the industrial advantages of large-scale production, technical specialization, business integration, functional socialization, and sustainable development. The development of a complete industrial chain entity can bring considerable benefits to the local economy, and the green is low. Carbon and high-end intelligence are the inevitable trend of economic development in all regions in the future. Therefore, actively transforming and developing new energy automobile industry is conducive to promoting high-quality, sustainable and healthy development of local economy.

\section{New Ideas for the Construction of Automobile Marketing under the Perspective of the Development of New Energy Automobile Industry}

With China's energy shortage and environmental pollution becoming more and more serious, the new energy automobile industry has become an important means to optimize the local economic structure and achieve local economic transformation. Therefore, in order to meet the development needs of the new energy automobile industry, the cultivation of new energy talents has become an important issue in upgrading the automobile industry and promoting the development of new energy vehicles, especially the talents in the marketing of new energy vehicles, which are directly related to the sales of new energy vehicles and Promotion. As the new energy automobile industry belongs to an emerging interdisciplinary industry, the current research on the industry in China is more in the technology itself. The research on the marketing talent training system for new energy vehicles is very rare, especially the professional setting and personnel training. In this context, this paper has carried out some research on the construction of automobile marketing under the perspective of the development of new energy automobile industry, hoping to better serve new energy automobile enterprises and effectively promote local economic development and transformation.

The new energy automobile industry involves the knowledge content of many disciplines such as vehicles, automotive electronics, natural gas, etc. For the cultivation of automotive marketing professionals, we must first improve the curriculum system of automotive marketing, not only to have professional sales knowledge, but also to cultivate them. Therefore, in the curriculum setting, the automotive marketing professional should add electrical control, hardware and software involved, testing, battery management and other courses. In addition, in the formulation of curriculum standards, combined with the specific needs of the actual work process of new energy vehicle marketing, comprehensive improvement should be made in terms of learning objectives setting, course positioning, learning content setting and evaluation indicators. The automotive marketing profession should not be constrained by the traditional curriculum system model, but should adopt the curriculum model of the employment system [7].

Considering that new energy vehicles belong to an emerging industry, in order to strengthen the 
practical ability of automotive marketing professionals, higher vocational colleges must also strengthen school-enterprise cooperation to provide more practical opportunities for automotive marketing students. In this process, higher vocational colleges can directly establish long-term cooperation mechanisms with off-campus enterprises, jointly agree on the direction of automobile marketing personnel training, and achieve a win-win development of schools and enterprises. In the specific implementation, higher vocational colleges can add the knowledge that the enterprises need to have in the automotive marketing course content. On this basis, the higher vocational colleges cooperate with the off-campus enterprises, which is beneficial to the automotive marketing students. Good control of the professional knowledge required for social practice.

At present, the new energy automobile industry is developing very rapidly. Both automotive technology and market trends are rapidly changing. This requires automotive marketing talents to be proficient in applying theoretical knowledge in specific practices and to learn to quickly apply theoretical knowledge to solve problems [8]. In fact, many higher vocational colleges in China are unsatisfactory in the cultivation of students' practical ability. After they are in the corresponding positions, they cannot complete their tasks independently or they cannot use their knowledge flexibly. This makes many enterprises feel embarrassed when they use people. In order to avoid such embarrassment, higher vocational colleges must strengthen the students' practical ability and the cultivation of their ability to apply learning. Especially in the context of the rapid development of the new energy automobile industry, higher vocational colleges must break the traditional teaching mode and theoretical practice. Combine to cultivate comprehensive high-quality talents with strong theoretical and practical skills.

From the perspective of the new energy automobile industry, the improvement of teachers' professional quality and the cultivation of students' ability are equally important. Only by perfecting the construction of higher-level teachers, can we cultivate more and more auto marketing talents. First of all, vocational colleges can hire some experts in the new energy vehicle industry or experienced technical personnel to train teachers to master the latest knowledge of the new energy vehicle industry. Secondly, the school can send some teachers with strong learning ability to the company for professional study and induction training. Finally, a "double-teacher-type teacher" reward mechanism was established to encourage teachers to conduct practical learning and strengthen their professional qualities.

\section{Conclusion}

As China's environmental pollution and energy shortages become more and more prominent, the development of new energy automobile industry has become an important way to realize the transformation of China's automobile industry and promote the sustainable development of China's economy. With the rapid development of the new energy automobile industry, the local economy can only truly realize the structural optimization of the local economy and the economic transformation by actively changing the concept and promptly responding to the national policy call to develop new industries such as green low-carbon and high-end intelligence. For higher vocational colleges, it should actively improve the curriculum of automotive marketing, and continuously improve the quality of teachers, so as to cultivate comprehensive automotive marketing talents with professional sales, management knowledge and knowledge of new energy vehicles, making it better for local Economic development of new energy automotive industry services.

\section{References}

[1] Wang Yang. Research on the Competitive Strategy of New Energy Automobile Enterprises in China [D]. Southeast University, 2017.

[2] Yang Binbin. Research on Industrial Transformation in Changchun City [D]. Jilin University, 2016. 
[3] Li Yuanhui. Research on the Green Competitive Capability of Chinese Automobile Manufacturing Enterprises in Low Carbon Economy [D]. Beijing Jiaotong University, 2016.

[4]Xu Laiwei. The road to transformation and development of Zhongzhan District Inject new kinetic energy into economic development [N]. Jiaozuo Daily, 2018-09-05 (004).

[5] Ge Xingyu. Research on the development strategy of automobile industry in Daqing City [D]. Northeast Petroleum University, 2014.

[6] Associate Professor of the Yellow River Civilization and Sustainable Development Research Center and the Yellow River Civilization Collaborative Innovation Center of Henan University Zhao Jianji. Vigorously develop emerging industries to create high-quality development new kinetic energy [N]. Henan Daily, 2018-09-05 (010).

[7] Ding Xuqiang. Research on the Construction of Applied Higher Vocational Teaching System_- Taking the Direction of New Energy Vehicles in Automobile Service Engineering of Nantong Institute of Technology as an Example[J]. Decision Making Exploration, 2018(04): 71.

[8] Lu Zongxia. Research on talent training mode of new energy vehicles [D]. Chang'an University, 2015. 